\title{
Disinfection Methods and Survival of SARS-CoV-2 in the Environment and Contaminated Materials: A Bibliometric Analysis
}

\author{
Adel Al-Gheethi ${ }^{1, *(\mathbb{D})}$, Mohammed Al-Sahari ${ }^{1}{ }^{1}$, Marlinda Abdul Malek ${ }^{2, *}$, Efaq Noman ${ }^{3,4}(\mathbb{D}$, \\ Qais Al-Maqtari ${ }^{5}$, Radin Mohamed ${ }^{1}$, Balkis A. Talip ${ }^{4}$, Sadeq Alkhadher ${ }^{1}$ and \\ Md. Sohrab Hossain ${ }^{6}$ \\ 1 Micropollutant Research Centre (MPRC), Faculty of Civil Engineering \& Built Environment, \\ Universiti Tun Hussein Onn Malaysia, Parit Raja 86400, Johor, Malaysia; \\ mohammedalsahari@gmail.com (M.A.-S.); maya@uthm.edu.my (R.M.); sadeqalkhather@yahoo.com (S.A.) \\ 2 Institute of Sustainable Energy, Universiti Tenaga Nasional, Selangor 43000, Malaysia \\ 3 Department of Applied Microbiology, Faculty of Applied Science, Taiz University, Taiz 00967, Yemen; \\ eanm1984@gmail.com \\ 4 Faculty of Applied Sciences and Technology, University Tun Hussein Onn Malaysia (UTHM), \\ Pagoh Higher Education Hub, KM 1, Jalan Panchor, Panchor 84000, Johor, Malaysia; balkis@uthm.edu.my \\ 5 Department of Biology, Faculty of Sciences, Sanaa University, Sanaa 00967, Yemen; qais.almaqtari@gmail.com \\ 6 School of Industrial Technology, University Sains Malaysia (USM), 11800 USM, Penang, Malaysia; \\ sohrab@usm.my \\ * Correspondence: adel@uthm.edu.my or adelalghithi@gmail.com (A.A.-G.); \\ Marlinda@uniten.edu.my (M.A.M.); Tel.: +60-19-332-2775 or +60-3-8921-2020 (M.A.M.); \\ Fax: +60-3-8921-2116 (M.A.M.)
}

Received: 22 July 2020; Accepted: 20 August 2020; Published: 9 September 2020

\begin{abstract}
The presence of SARS-CoV-2 in sewage and water resources has been used as an indication for the possible occurrence of the virus among communities and for its potential of transmission among humans through the surrounding environment or water resources. In order to reduce the transmission of SARS-CoV-2, contaminated surfaces should be disinfected frequently by using an effective disinfectant. The present review discusses a bibliometric analysis of the global SARS-CoV-2 research and focuses mainly on reviewing the efficiency of the most traditional disinfection technologies. The disinfection methods reviewed include those for hospitals' or medical facilities' wastewater, contaminated surfaces, and contaminated masks. The elimination of the virus based on the concept of sterility assurance level (SAL) is also discussed. In addition, the chemical disinfectants that are currently used, as well as their temporary efficiency, are also reviewed. The different technologies that are globally used for disinfection processes during the COVID-19 pandemic are shown. However, more advanced technologies, such as nanotechnology, might have more potential for higher inactivation effectiveness against SARS-CoV-2.
\end{abstract}

Keywords: disinfection; COVID-19; sterility assurance level; medical masks; inactivation; UV irradiation

\section{Introduction}

The genus of coronavirus is composed of at least three genetically and antigenically distinct groups of $\mathrm{CoV}$ that cause mild to severe enteric, respiratory, or systemic disease in domestic and wild animals, poultry, rodents, and carnivores, as well as mild colds in humans. SARS-CoV-2, from the genus of coronavirus, is an enveloped and positive-sense virus with single-stranded RNA. However, SARS-CoV-2 has a high potential to cause respiratory or systemic illnesses in humans. 
The zoonotic transmission of this virus has been reported in several regions, including a severe acute respiratory syndrome $\mathrm{CoV}$ (SARS-CoV) infection, which was transmitted from bats and the Himalayan palm civet (Paguma larvata) in 2002-2003 in China, and the Middle East respiratory syndrome CoV (MERS-CoV), which has been transmitted from dromedary camels (Camelus dromedaries) in the Arabian Peninsula since 2012. SARS-CoV-2 causes self-limiting upper- and lower-respiratory infections in people with immunocompetence. It has been detected that SARS-CoV- 2 has $89 \%$ similarity in the nucleotide sequences to bat SARS-like-CoVZXC21, while it has $82 \%$ similarity to the human SARS-CoV genome [1-3].

One of the main serious problems with SARS-CoV-2 is the transmission route. It has been revealed that the virus has a clear transmission route through respiratory droplets and survives for more than one day in the environment. It is hypothesized that there is a risk of exposure to the virus on environmental surfaces, which has not yet been proven. Thus, indoor and outdoor surfaces should be disinfected frequently [4,5]. This study presents a bibliometric analysis of global SARS-CoV-2 research and focuses mainly on reviewing the efficiency of the most traditional disinfection technologies on contaminated surfaces, medical masks, and hospital wastewater, which have a higher probability of having greater loads of the virus. The elimination of the virus based on the concept of sterility assurance level is also discussed.

\section{Bibliometric Analysis of SARS-CoV-2 in the Literature}

Literature data were collected from the SCOPUS database by restricting the search to all published documents from 1 January, 2019 to 24 June, 2020 under the keywords "SARS-CoV-2" AND "Transmission Route" OR "Genomic Map" OR "Pathogenicity" OR "Symptoms" OR “Therapeutics" OR "Survival" OR "Environment", from which 2000 documents were obtained. The bibliometric analysis used various bibliometric ranking indices, including the top journals, countries, and the most frequent keywords in the obtained documents. The worldwide distribution of documents was used to clarify the connections and relationships between terms, keywords, and countries as well as to establish a rainbow density map of bibliographic coupling and countries of publication in this area, as presented in Figures 1-3. In the current review, the top countries are shown in the bibliometric map of the published documents and their links among countries (Figure 1). A circle's size indicates a country's number of publications, while the color of the circle refers to the utilized keywords. In the same sense, the connected lines between countries express the citations and the link strengths between the publications of each country. It was noted that most research conducted on SARS-CoV-2 was performed in the USA, followed by China and Italy. The Journal of Medical Virology and Journal of Medical Hypotheses were the top journals that published high numbers of SARS-CoV-2 articles (Figure 2). The articles addressed the infection among females, the isolation and purification of the virus for further studies, genetic mapping, and the symptoms of the infections, such as fever (Figure 3). 


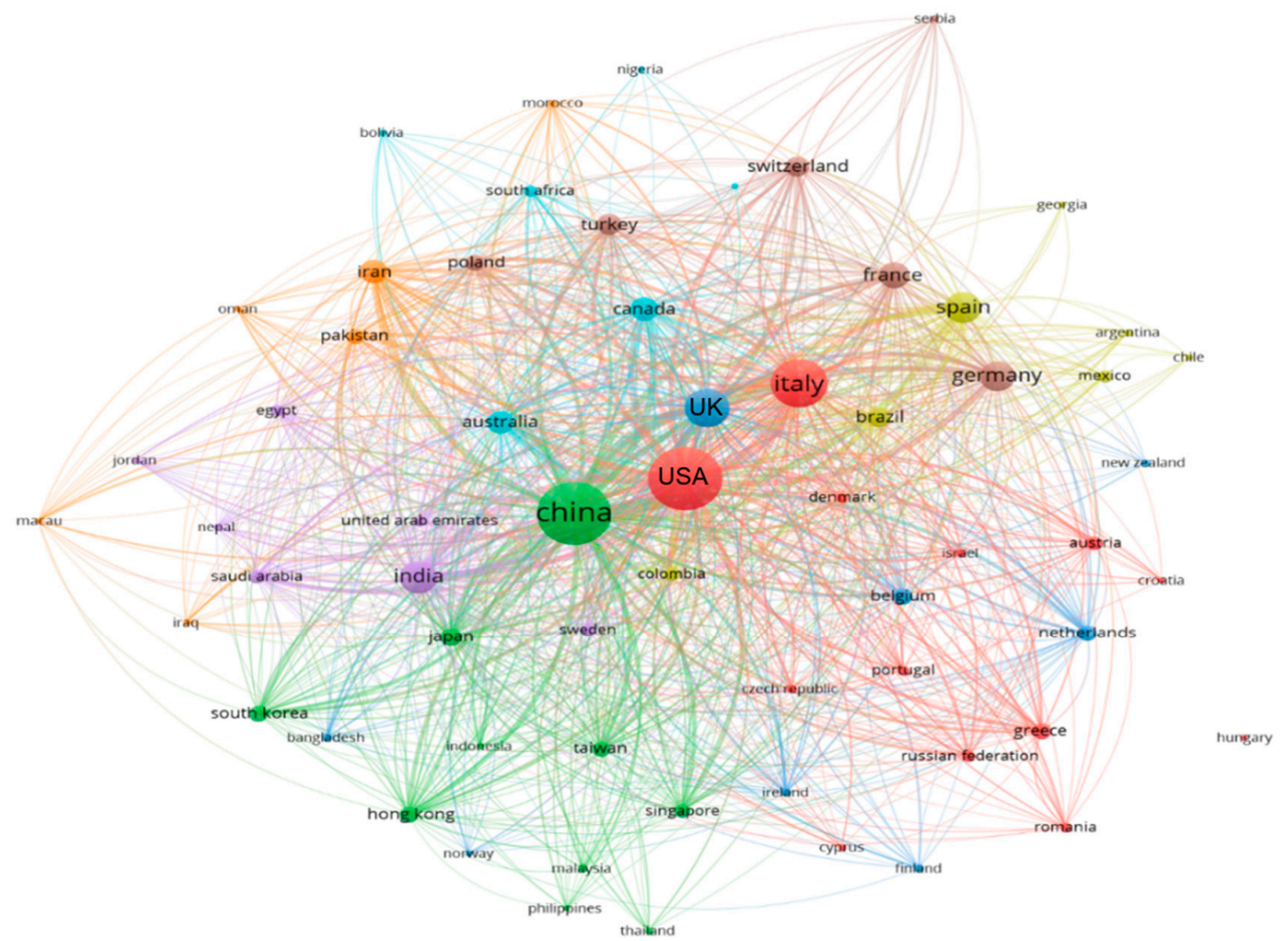

Figure 1. Bibliographic map of the publisher countries of SARS-CoV-2 documents listed in the SCOPUS database (2019 to 22/07/2020).

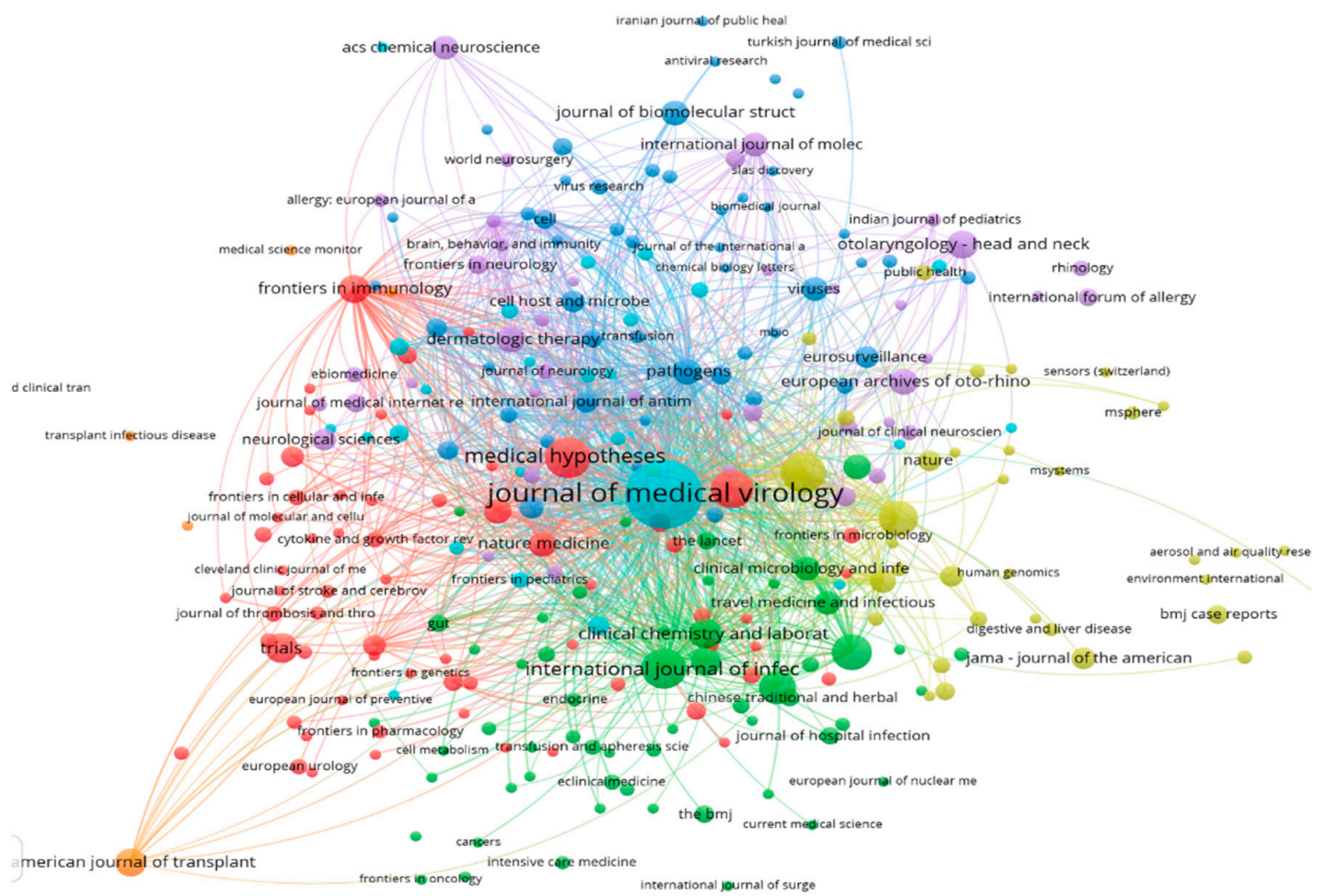

Figure 2. Bibliographic map of the publisher Journals of the published SARS-CoV-2 documents listed in the SCOPUS database (2019 to 22/07/2020). 


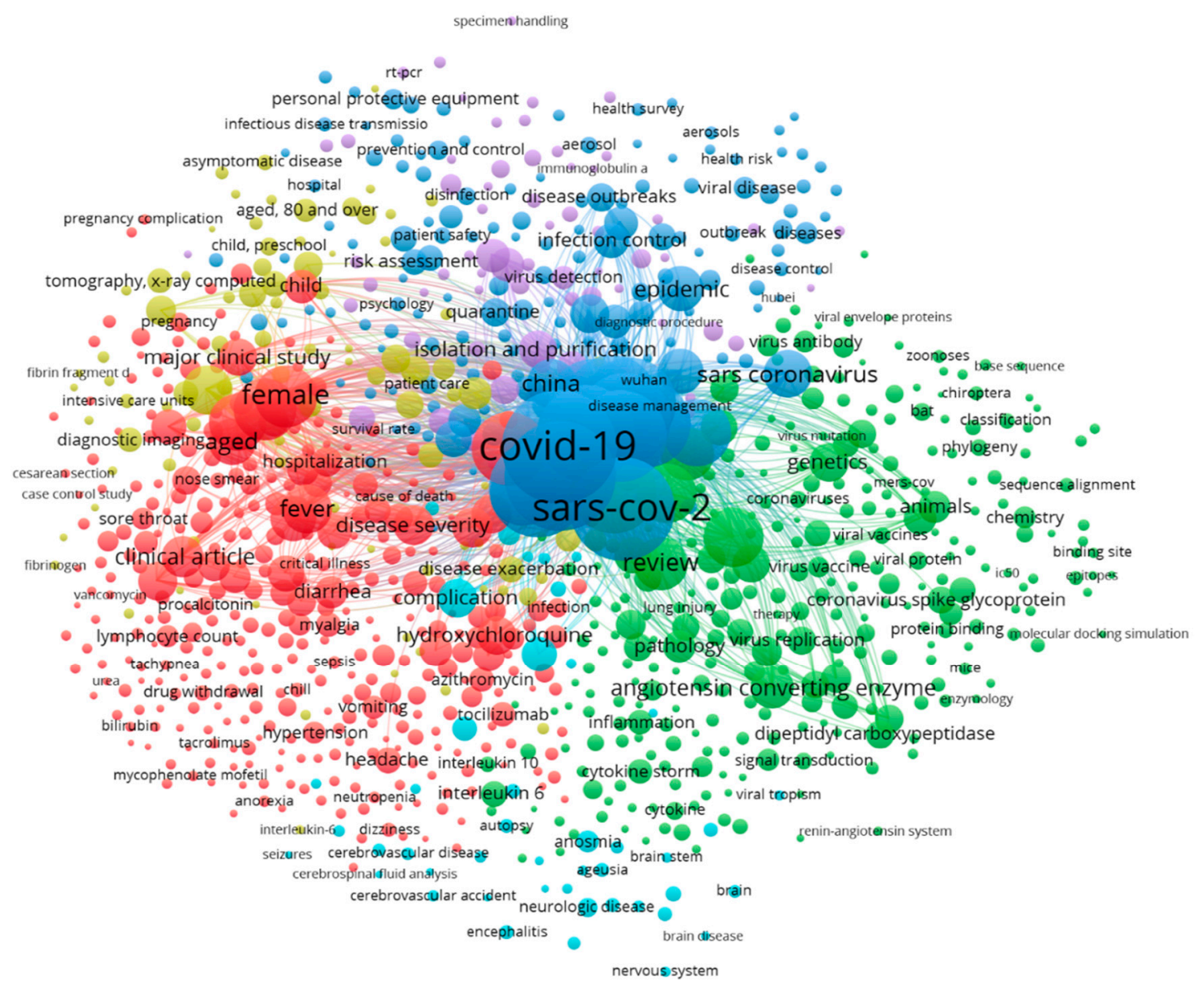

Figure 3. Bibliographic map of the keywords used in the published SARS-CoV-2 documents listed in the SCOPUS database (2019 to 22/07/2020).

The main findings of the reviewed articles are summarized in Figure 4 . In order to focus on the literature within the study scope, all reviews were categorized into five sections, including the sources of the SARS-CoV-2 pandemic, pathogenicity and symptoms, transmission, diagnostic and genome organization, and therapeutics that are associated with the research objectives.

The life cycle of the virus is presented in Figure 5. The virus enters into the cell cytoplasm through the ACE2 receptors available on the surface of the human cells. The virus genome is multiplied inside the cells and each of the new genomes is enveloped by the cell membrane and then released to infect a new cell. 


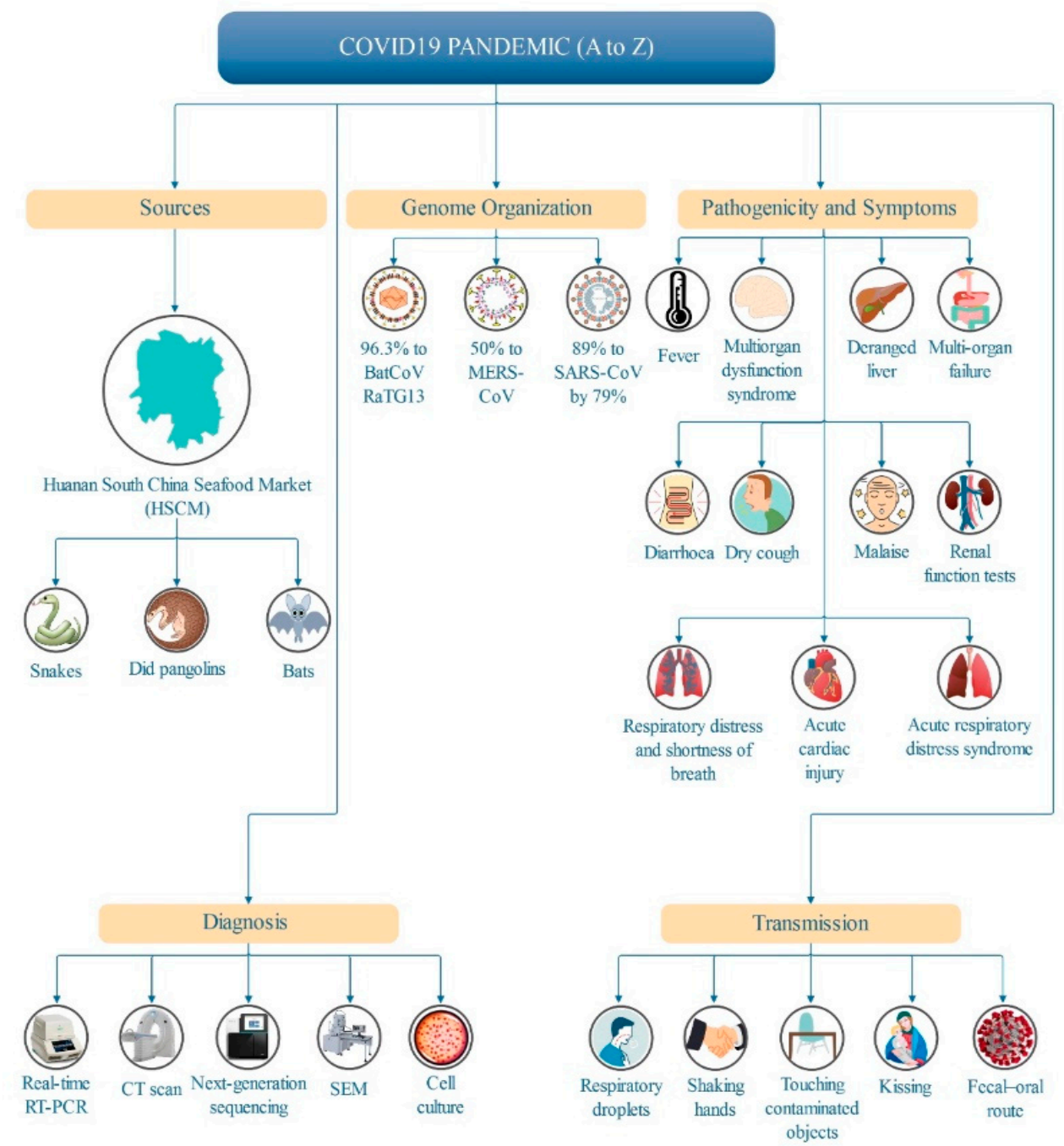

Figure 4. Main findings of SARS-CoV-2 documents listed in the SCOPUS database (2019 to 22/07/2020).

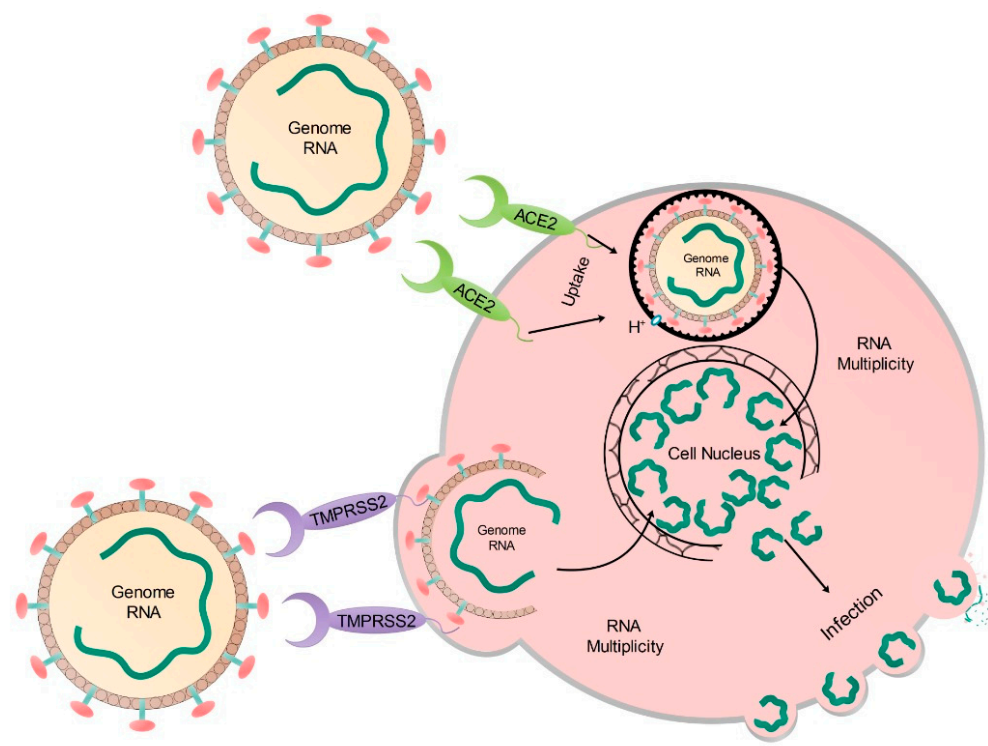

Figure 5. SARS-CoV-2 cycle in the human cells. 


\section{SARS-CoV-2 in Wastewater}

Hospitals' and medical facilities' wastewater may contain significant numbers of microbial communities including pathogenic bacteria and viruses. With the emergence of the novel coronavirus, scientists are now facing challenges in understanding its potential faecal-oral transmission and its association with the environmental pollutants originating from the disposal of hospital wastewater. It has been indicated by researchers in the literature that the pathogenicity and virulence factors of the infectious agents lie in their ability to survive in the environment as well as their potential to transmit into humans and animals without a host cell [6]. Hospital and medical facilities' effluents should be subjected to an efficient disinfection process before final disposal into the environment. There are two factors that should be considered for any disinfection process, namely the biological indicators and the assessment procedure. The selection of an indicator for evaluating the efficiency of the disinfection process depends on the nature of the inactivation process, including chemical or physical processes. The response of indicator organisms reflects the behavior of infectious agents. For instance, bacteriophages are used as an indicator for human viral pathogens [7].

Although there are no scientific reports on the presence of SARS-CoV-2 in sewage, a number of studies have reported high levels of viral shedding on fecal samples derived from SARS-CoV-2 patients $[8,9]$. In addition, several news reports in France and the Netherlands have reported the presence of SARS-CoV-2 gene fragments in sewage and water surfaces [9].

\section{Treatment of Hospital Wastewater Contaminated with SARS-CoV-2}

Many of the treatment processes used in treating wastewater focused mainly on inactivating pathogenic bacteria that are harmful to aquatic life. However, recent studies have revealed a detectable number of pathogens that remained in effluents even after they underwent sewage treatment [10]. Chlorine is one of the most common disinfectants used in hospitals and medical facilities. In addition to being effective in killing most microbial communities, this detergent has a negative effect on the environment, which may be harmful to aquatic life if these contaminants enter the streams. Chlorination may also lead to the production of nitrosodimethylamine (NDMA), which is known to be carcinogenic to humans. The chlorination process can react with organic matter, forming another carcinogenic compound called trihalometanes (THMs) [11]. Conventional filtration techniques employed in wastewater treatment are not highly effective in removing micropollutant such as viruses. In addition, some microbes were found to be resistant to certain types of chemical materials. These findings are consistent with the study reported by Al-Gheethi et al. [12], which showed the presence of viable microbial cells even after going through the treatment process.

The use of solar-based disinfection (SODIS) technology is a promising approach, especially in the process of disinfection of water and wastewater. This technology is suitable based on the availability of high solar radiation, and is characterized by low resources cost and sustainability [13]. Meanwhile, the application of nanotechnology in wastewater treatment has also been reported in the literature [14]. For instance, Noman et al. [15] investigated the inactivation of antibiotic-resistant Escherichia coli (Gram-negative) and Staphylococcus aureus (Gram-positive) seeded in greywater by bimetallic bio-nanoparticles. The bimetallic nanoparticles $(\mathrm{Zn} / \mathrm{Cu} \mathrm{NPs})$ were biosynthesized in secondary metabolite of a novel fungal strain identified as Aspergillus iizukae EAN605. This study revealed the high efficiency of $\mathrm{Zn} / \mathrm{Cu}$ NPs in inhibiting the growth of E. coli and S. aureus. The inactivation mechanism showed that the bacterial cells were inactivated due to the damage in the cell wall structure. This is due to the degradation of carbohydrates and protein structures of the bacterial cell wall. Analysis using Fourier transform infrared spectroscopy (FTIR) confirmed that destruction has occurred in the $\mathrm{C}-\mathrm{C}$ bond of the functional groups found in the bacterial cell wall. The combination between SODIS and nanotechnology might provide a novel process of disinfection in inactivating human viruses. $\mathrm{ZnO}$ are the most common nanoparticles used for wastewater disinfection and these particles were reported to be more effective under sunlight, which might increase the antiviral activity [16,17]. Wastewater treatment plants are usually operated all days of the week for 24 hours. In many places 
located far from the Equator, solar radiation is very limited in winter and the solar radiation is depleted during night; hence, SODIS is not a suitable method to employ in these areas. In addition, adequate $\mathrm{UV}$ radiation cannot penetrate the surface of wastewater effectively. Therefore, if UV radiation is used, treatment should be performed using a reactor, where wastewater is mixed and drained under UV lamps. Nonetheless, Kibbee and Örmeci [18] stated that peracetic acid (PAA) with low-pressure ultraviolet (LP-UV) radiation can inactivate Coxsackievirus B3 (CVB3) in municipal wastewater.

Sterility assurance level (SAL) is a term used to describe the killing efficiency of a treatment process, where the treatment process is very effective if the SAL is very low, as described by ISO 13408-1 [19], and log reduction (accepted by United States Environmental Protection Agency USEPA) is a term that is commonly used for assessing the efficiency of the disinfection processes. SAL is usually expressed as $10^{-n}$. A $10^{-3}$ or $10^{-6}$ value is most often used for sterilization depending on the initial concentration of the pathogen. Log reduction is calculated as $\left(10^{-1}\right)$, representing a $90 \%$ reduction in microbial population. The process of disinfection with a $6 \log$ reduction $\left(10^{-6}\right)$ indicates that the microbial population decreases from one million $\left(10^{6}\right)$ to almost zero, or a reduction of $99.9999 \%$. A kill rate of $99.99 \%$ is expressed in the form of a $4 \log$ reduction.

In order to confirm that the removal of treated effluent is safe, the growth of inactive bacteria should be determined as an indicator for inactive viruses. Therefore, samples should be isolated and cultured on enrichment media. These cells are considered killed if no growth can be seen in the culture medium after the incubation period. However, the storage conditions of disinfected samples may affect the ability of microbial cells to resuscitate. Al-Gheethi et al. [20] revealed that Salmonella spp. S. aureus and $E$. faecalis were resuscitated in sewage samples treated with solar disinfection (SODIS) for $6 \mathrm{~h}$ and stored at $37^{\circ} \mathrm{C}$ for 4 days. The survival of cells may occur due to the insufficiency of the disinfection process to damage the cell walls of the bacteria and in this case the pathogen growth potential (PGP) bioassay needs to be carried out.

\section{Disinfection of Sars-Cov-2 in Contaminated Surfaces}

The efficiency of several disinfectants against microbes depends on the ability to create an irreversible destruction of microbial cells. Thus, several methods can be used including the process of physical and chemical disinfection.

However, the concept of chemical disinfection depends on the inhibition of a critical metabolic and anabolic pathways that cause microbial activity to be irreversibly inhibited. For some types of microbes, the cell has an alternative metabolic pathway, which can cause the cell to remain active even after disinfection. On the other hand, the physical disinfection is dependent on the destruction of the cytoplasm. This damage is irreversible when microbial cells do not have the potential to recover to normal activity due to damage to the cells' enzymes.

Many studies have been conducted to better understand the mechanism of action of antibacterial disinfectants. By contrast, similar studies on viruses are relatively sparse. Viruses have no metabolic activity. Therefore, studies related to whether the disinfectant agent used can inactivate prions are still limited. However, a study has reported that lipophilic disinfectants and chaotropic agents have little difficulty in reacting to a normal lipid bilayer [19]. The veridical efficiency of chemical disinfection may act by denaturing virus envelops, which are derived from portions of host cell membranes (phospholipids and proteins). Nonetheless, the denaturation of the virus envelop may not cause damage to the virus genome. Thus, many chemical disinfectants, such as alcohol (70\%), chlorine, soap, and detergent may be inadequately effective in inactivating the virus genome. Physical disinfection, such as temperature and pressure, would be more effective due to its ability to destruct both the viral envelope and the genome.

Another limitation in the use of chemical disinfectants is their stability in the environment. The inactivation of viruses on contaminated surfaces by using alcohol or detergents may work immediately. However, the ability of disinfectants to kill viruses on the surface in outdoor areas, which are exposed to pollutants, is limited. This is because the coverage rate of detergents is limited, 
and it is possible that the detergent is not evenly distributed. Alcohol and other disinfectants loss their activity against the viruses or any microbes after a few minutes due to high evaporation rates, especially in tropical countries. It has been demonstrated that the natures of chemical disinfectants play an important role in determining their efficacy. This process is influenced by environmental parameters, such as temperature and relative humidity.

In the chlorination of water and wastewater, there is an amount of residual chlorine that constitutes an important safeguard against the risk of subsequent microbial contamination after treatment [20]. The diluted chlorine is also effective to inactivate the virus. The diluted chlorine should be freshly prepared due to its sensitivity to light, which may cause it to lose its effectiveness [21]. Residual chlorine is not available for surface disinfection. Thus, outdoor surfaces, such as in public transport, are recommended to be disinfected frequently. For this reason, there is an urgency to find a disinfectant that contains stable active ingredients, which can be used to frequently combat surface contamination, particularly in open public areas. SARS-CoV-2 has the ability to survive for longer periods (possibly up to 24 hours) compared to chemical disinfectants that disperse on contaminated surfaces. This is because chemical disinfectants have short stability. By contrast, nanoparticles have a longer stability in the environment. This has been proven by a study of the use of nanoparticles against the H1N1 virus in different environments [17].

NPs biosynthesis represents an alternative to chemical and physical synthesis processes. For example, the surface of fungal cells consists of proteins, enzymes, and reducing components that produce reducing agents, such as napthoquinones and anthraquinones [22]. Therefore, the use of fungi as stabilizing/reducing agents is very effective in producing NPs. Moreover, fungi have a significant morphology, as they can produce various types of intracellular enzymes for the development of metal and metal oxide NPs. Various species of fungi have been used in synthesizing NP metals due to their high binding capacity and ability to bioaccumulate metals as well as their intracellular uptake. The biosynthesis of NPs using fungi is better than other microorganisms because fungi are easy to isolate, grow fast, and can be cultured in the laboratory [15].

ZnO-NPs with a size of less than $100 \mathrm{~nm}$ may have the potential to inactivate SARS-CoV-2 (with a size of $400 \mathrm{~nm}$ ) and physically destroy the viral genome. In addition, ZnO-NPs plays a dual role as an anti-adhesive and antimicrobial agent simultaneously. It also has the ability to stabilize on the surface under different humidity and ambient conditions [23]. Because SARS-CoV-2 poses a high risk of infection, studies on the effectiveness of nano-disinfectants have been initiated using bacteriophage as a modal organism.

\section{Disinfection of Disposable Medical Face Masks Contaminated with SARS-CoV-2}

The use of disposable masks such as respirators facial filters (N95), medical face masks, and other face masks (such as non-medical, cloth, or barrier masks) during the SARS-CoV-2 pandemic has increased the amount of waste. A WHO report [24] states that approximately 89 million medical masks are needed each month in dealing with this pandemic. Accordingly, the disposal of this mask to the environment, especially among public users, without undergoing the process of disinfection may contribute to the spread of the virus. Several countries have adopted regulation for reuse of disposable masks, as studied by Rubio-Romero et al. [25]. These regulations are used to ensure that the disinfection process is carried out in accordance with the mandated procedure. The choice of disinfection process depends on the type of mask and the species of the virus.

It has been reported that the survival period of the COVID-19 virus ranges from few hours $(72 \mathrm{~h}$ ) to several days, which might reach up to 9 days $[26,27]$. The most common disinfectants used are ethanol $(62-71 \%)$, hydrogen peroxide $(0.5 \%)$ and sodium hypochlorite $(0.1 \%)$. These disinfectants have the ability to inactivate the virus within 1 minute, since the inactivation process depends on the oxidation reactions. Heat sterilization may be more efficient in disinfection. However, it is not suitable for direct use because most masks are sensitive to high temperatures [28]. Some references have recommended to keep the mask for at least five days before reuse. However, all masks that have 
been used will eventually be disposed of into the environment, which may cause virus transmission. Therefore, it is important to find an effective and safe disinfection process before disposing or reuse.

Disinfection methods are categorized into two types, namely chemical methods (by using $\mathrm{H}_{2} \mathrm{O}_{2}$, bleach, chlorine dioxide, soap solutions, alcohol, ozone or ethylene oxide) and physical methods (heat, steam autoclave, dry air, microwaves, gamma irradiation or UV irradiation) [29]. To date, many studies have focused on non-thermal disinfection, which depends on high pressure (which may reach to $40 \mathrm{MPa})$, such as supercritical carbon dioxide $\left(\mathrm{SC}^{-} \mathrm{SO}_{2}\right)$. This technology is more suitable than others because there is no toxic by-product generated, as in the case of chemical methods [30]. However, the SC- $\mathrm{CO}_{2}$ instrument is very expensive and not applicable for personal use. Medical masks are not classified as clinical waste unless they have been contaminated with blood. In addition, more than $90 \%$ of these masks are used by the public for non-medical use. Thus, these masks are not subject to clinical waste management. Chemical disinfectants are more suitable for individual use. Due to these limitations, treatment methods using UV radiation have been widely used compared to other methods.

Studies in the literature have revealed that UV radiation (pulsed xenon ultraviolet (PX-UV)) is effective in inactivating the Ebola virus on glass carriers and Polyethylene terephthalate (PET) materials [31]. O'Hearn et al. [32] concluded that ultraviolet germicidal irradiation (UVGI) with a dose of $40,000 \mathrm{~J} / \mathrm{m}^{2}$ was effective for disinfecting N95 masks. The main advantage of disinfection using UVGI is that it does not degrade the polymers if a double $36 \mathrm{~W}$ lamp is used and the inactivation process occurs within $148 \mathrm{~s}$ from the time of exposure. According to Rubio-Romero et al. [25], radiation through $254 \mathrm{~mm}$ UV light has high efficacy for disinfection during the COVID-19 pandemic. ultraviolet light (UV-C) is also used as one of the disinfection methods. However, one of the disadvantages of its use is the inability to reach the inner layer of the masks. However, the use of a pair of UV lamps (above and below the mask) can enhance the inactivation process. Furthermore, the efficiency of UV in inactivating and killing viruses must be confirmed based on the concept of sterility assurance level (SAL).

\section{Survival of SARS-CoV-2 in the Air}

Many studies have been conducted to investigate the survivability of SARS-CoV-2 in aerosols. These studies have revealed that the survivability of the virus depends on the moisture and size of droplets. Larger droplets, which can only travel through aerosols at a short distance, settle down very quickly. Nonetheless, as saliva droplets have a longer drying time, viable viral cells present in the saliva droplets can easily be transmitted through direct contact. It has been reported that the survival period of the virus in aerosols and on a surface ranges from $3 \mathrm{~h}$ to several days, depending on the type of the surface, as presented in Table 1 [33-35].

Table 1. Survival period of Sars-Cov-2 in aerosol and on different surfaces.

\begin{tabular}{cc}
\hline Surface & Survival Time \\
\hline Aerosols & $3 \mathrm{~h}$ \\
Plastic & 3 days \\
Stainless steel & $2-5$ days \\
Cardboard & $8 \mathrm{~h}$ \\
Paper & 5 min to 5 days \\
Glass & $4-5$ days \\
Polyvinyl chloride (PVC) & 5 days \\
Silicon rubber & 5 days \\
Surgical gloves (latex) & 5 days \\
Polyfluorotetraethylene (PTFE) & 5 days \\
\hline
\end{tabular}

The ability of SARS-CoV-2 to survive for different periods of time on different surfaces depends on the properties of a surface. For example, the ability to absorb moisture plays an important role in the adhesion of viral particles. The virus is transmitted from an infected person to the air with a 
droplet adhesion mechanism that depends on the droplet size (aerosol), where smaller droplets are more easily suspended in air than larger droplets.

\section{Conclusions}

The presence of SARS-CoV-2 in water and wastewater indicates the potential for the spread of the virus in the environment. However, there is no evidence to show that DNA fragments detected in water and wastewater are pathogenic. In addition, the survival of the virus on surfaces requires effective disinfection to ensure that the virus has become inactive.

Author Contributions: Conceptualization, A.A.-G. and E.N.; methodology, Q.A.-M. and M.A.-S.; software, A.A.-G. and M.A.-S.; validation, R.M., M.A.M., Q.A.-M. and B.A.T.; investigation, S.A.; resources; data curation, M.S.H.; writing-original draft preparation, A.A.-G.; writing—review and editing, R.M. and M.A.M.; visualization, E.N.; supervision, R.M. and M.A.M.; project administration, A.A.-G.; funding acquisition, M.A.M. All authors have read and agreed to the published version of the manuscript.

Funding: The research was funded by UNITEN RMC Internal Research Grant: RJO 10517919/iRMC/Publication.

Acknowledgments: The Authors would like to acknowledge Ministry of Higher Education Malaysia (MoHE) under the Fundamental Research Grant Scheme, (FRGS) FRGS/WAB05/UTHM/02/5.

Conflicts of Interest: The authors declare no conflict of interest.

\section{References}

1. Woo, P.C.; Lau, S.K.; Chu, C.M.; Chan, K.H.; Tsoi, H.W.; Huang, Y.; Wong, B.H.; Poon, R.W.; Cai, J.J.; Luk, W.K.; et al. Characterization and complete genome sequence of a novel coronavirus, coronavirus HKU1, from patients with pneumonia. J. Virol. 2005, 79, 884-895. [CrossRef] [PubMed]

2. Chan, J.F.; Kok, K.H.; Zhu, Z.; Chu, H.; To, K.K.; Yuan, S.; Yuen, K.Y. Genomic characterization of the 2019 novel human-pathogenic coronavirus isolated from a patient with atypical pneumonia after visiting Wuhan. Emerg. Microbes Infect. 2020, 9, 221-236. [CrossRef] [PubMed]

3. Liu, Y.; Rosenfield, E.; Hu, M.; Mi, B. Direct observation of bacterial deposition on and detachment from nanocomposite membranes embedded with silver nanoparticles. Water Res. 2013, 47, 2949-2958. [CrossRef] [PubMed]

4. Gralinski, L.E.; Menachery, V.D. Return of the Coronavirus: 2019-nCoV. Viruses 2020, 12, 135. [CrossRef]

5. Wang, M.; Cao, R.; Zhang, L.; Yang, X.; Liu, J.; Xu, M.; Shi, Z.; Hu, Z.; Zhong, W.; Xiao, G. Remdesivir and chloroquine effectively inhibit the recently emerged novel coronavirus (2019-nCoV) in vitro. Cell Res. 2020, 4, 1-3. [CrossRef]

6. Ceustermans, A.; De Clercq, D.; Aertsen, A.; Michiels, C.; Geeraerd, A.; Van Impe, J.; Coosemans, J.; Ryckeboer, J. Inactivation of Salmonella Senftenberg strain W 775 during composting of biowastes and garden wastes. J. Appl. Microbiol. 2007, 103, 53-64. [CrossRef]

7. Dias, E.; Ebdon, J.; Taylor, H. The application of bacteriophages as novel indicators of viral pathogens in wastewater treatment systems. Water Res. 2018, 129, 172-179. [CrossRef]

8. Hindson, J. COVID-19: Faecal-oral transmission? Nat. Rev. Gastroenterol. Hepatol. 2020, 17, 259. [CrossRef]

9. Chen, Y.; Chen, L.; Deng, Q.; Zhang, G.; Wu, K.; Ni, L.; Yang, Y.; Liu, B.; Wang, W.; Wei, C.; et al. The Presence of SARS-CoV-2 RNA in Feces of COVID-19 Patients. J. Med. Virol. 2020, 92, 833-840. [CrossRef]

10. Spongberg, A.L.; Witter, J.D. Pharmaceutical compounds in the wastewater process stream in Northwest Ohio. J. Sci. Environ. 2008, 397, 148-157. [CrossRef]

11. Kumari, M.; Gupta, S.K.; Mishra, B.K. Multi-exposure cancer and non-cancer risk assessment of trihalomethanes in drinking water supplies-A case study of Eastern region of India. Ecotoxicol. Environ. Saf. 2015, 113, 433-438. [CrossRef] [PubMed]

12. AL-Gheethi, A.A.; Ismail, N.; Lalung, J.; Talib, A.; Kadir, M.O.A. Reduction of Faecal Indicators and Elimination of Pathogens from Sewage Treated Effluents by Heat Treatment. Casp. J. Appl. Sci. Res. 2013, 2, 39-55.

13. Gomez-Couso, H.; Fontan-Sainz, M.; Sichel, C.; Fernandez-Ibanez, P.; Ares-Mazas, E. Efficacy of the solar water disinfection method in turbid waters experimentally contaminated with Cryptosporidium parvum oocysts under real field conditions. Trop. Med. Int. Health 2009, 14, 620-627. [CrossRef] [PubMed] 
14. Athirah, A.; Al-Gheethi, A.A.S.; Noman, E.A.; Mohamed, R.M.S.R.; Kassim, A.H.M. Centralised and decentralised transport systems for greywater and the application of nanotechnology for treatment processes. In Management of Greywater in Developing Countries; Springer: Cham, Switzerland, 2019; pp. 227-244.

15. Noman, E.; Al-Gheethi, A.; Talip, B.A.; Mohamed, R.; Kassim, A.H. Inactivating pathogenic bacteria in greywater by biosynthesized $\mathrm{Cu} / \mathrm{Zn}$ nanoparticles from secondary metabolite of Aspergillus iizukae; optimization, mechanism and techno economic analysis. PLoS ONE 2019, 14. [CrossRef]

16. Siddiqi, K.S.; Husen, A. Fabrication of metal nanoparticles from fungi and metal salts: Scope and application. Nano Res. Lett. 2016, 11, 98. [CrossRef]

17. Ghaffari, H.; Tavakoli, A.; Moradi, A.; Tabarraei, A.; Bokharaei-Salim, F.; Zahmatkeshan, M.; Farahmand, M.; Javanmard, D.; Kiani, S.J.; Esghaei, M.; et al. Inhibition of H1N1 influenza virus infection by zinc oxide nanoparticles: Another emerging application of nanomedicine. J. Biomed. Sci. 2019, 26, 70. [CrossRef]

18. Kibbee, R.; Örmeci, B. Peracetic acid (PAA) and low-pressure ultraviolet (LP-UV) inactivation of Coxsackievirus B3 (CVB3) in municipal wastewater individually and concurrently. Water Res. 2020, 183, 116048. [CrossRef]

19. ISO. International Standard Organisation. Aseptic Processing of Health Care Products, Part 1, General Requirements; International Standard ISO 13408-1 1998; International Standard Organisation: Geneva, Switzerland, 1998.

20. Al-Gheethi, A.A.; Efaq, A.N.; Bala, J.D.; Norli, I.; Abdel-Monem, M.O.; Kadir, M.A. Removal of pathogenic bacteria from sewage-treated effluent and biosolids for agricultural purposes. Appl. Water Sci. 2018, 8, 74. [CrossRef]

21. Trajano, D.; Dias, E.; Ebdon, J.; Taylor, H. Limitations of chlorine disinfection of human excreta: Implications for Ebola disease control. In Proceedings of the 39th WEDC International Conference, Kumasi, Ghana, 11-15 July 2016.

22. Siddiqi, K.S.; ur Rahman, A.; Husen, A. Properties of zinc oxide nanoparticles and their activity against microbes. Nanoscale Res. Lett. 2018, 13,1-13. [CrossRef]

23. Liu, Z.; Magal, P.; Seydi, O.; Webb, G. Understanding Unreported Cases in the 2019-Ncov Epidemic Outbreak in Wuhan, China, and the Importance of Major Public Health Interventions. Biology 2020, 9, 50. [CrossRef]

24. WHO. Shortage of Personal Protective Equipment Endangering Health Workers Worldwide. 2020. Available online: https://www.who.int/news-room/detail/03-03-2020-shortage-of-personal-protective-equipmentendangering-health-workers-worldwide (accessed on 3 April 2020).

25. Rubio-Romero, J.C.; del Carmen Pardo-Ferreira, M.; García, J.A.T.; Calero-Castro, S. Disposable masks: Disinfection and sterilization for reuse, and non-certified manufacturing, in the face of shortages during the COVID-19 pandemic. Saf. Sci. 2020, 129, 104830. [CrossRef] [PubMed]

26. Günter, K.; Todt, D.; Pfaender, S.; Steinmann, E. Persistence of coronaviruses on inanimate surfaces and their inactivation with biocidal agents. J. Hosp. Infect. 2020, 104, 246-251.

27. Van Doremalen, N.; Bushmaker, T.; Morris, D.H.; Holbrook, M.G.; Gamble, A.; Williamson, B.N.; Tamin, A.; Harcourt, J.L.; Thornburg, N.J.; Gerber, S.I.; et al. Aerosol and surface stability of SARS-CoV-2 as compared with SARS-CoV-1. N. Engl. J. Med. 2020, 382, 1564-1567. [CrossRef] [PubMed]

28. Rowan, N.J.; Laffey, J.G. Challenges and solutions for addressing critical shortage of supply chain for personal and protective equipment (PPE) arising from Coronavirus disease (COVID19) pandemic-Case study from the Republic of Ireland. Sci. Total Environ. 2020, 725, 138532. [CrossRef] [PubMed]

29. Mohapatra, S. Sterilization and disinfection. In Essentials of Neuroanesthesia; Academic Press: Cambridge, MA, USA, 2017; pp. 929-944.

30. Efaq, A.N.; Rahman, N.N.N.A.; Nagao, H.; Al-Gheethi, A.; Shahadat; Kadir, M.O.A. Supercritical carbon dioxide as non-thermal alternative technology for safe handling of clinical wastes. Environ. Process. 2015, 2, 797-822. [CrossRef]

31. Jinadatha, C.; Simmons, S.; Dale, C.; Ganachari-Mallappa, N.; Villamaria, F.C.; Goulding, N.; Tanner, B.; Stachowiak, J.; Stibich, M. Disinfecting personal protective equipment with pulsed xenon ultraviolet as a risk mitigation strategy for health care workers. Am. J. Infect. Control 2015, 43, 412-414. [CrossRef]

32. Katie, O.; Gertsman, S.; Sampson, M.; Webster, R.; Tsampalieros, A.; Ng, R.; Gibson, J.; Lobos, A.-T.; Acharya, N.; Agarwal, A.; et al. Decontaminating N95 masks with Ultraviolet Germicidal Irradiation (UVGI) does not impair mask efficacy and safety: A Systematic Review. J. Hosp. Infect. 2020, 106, 163-175. 
33. Fiorillo, L.; Cervino, G.; Matarese, M.; D’Amico, C.; Surace, G.; Paduano, V.; Fiorillo, M.T.; Moschella, A.; La Bruna, A.; Romano, G.L.; et al. COVID-19 Surface Persistence: A Recent Data Summary and Its Importance for Medical and Dental Settings. Int. J. Environ. Res. Public Health 2020, 17, 3132. [CrossRef]

34. Wang, J.; Zhou, M.; Liu, F. Reasons for healthcare workers becoming infected with novel coronavirus disease 2019 (COVID-19) in China. J. Hosp. Infect. 2020, 105, 100-101. [CrossRef]

35. Warnes, S.L.; Little, Z.R.; Keevil, C.W. Human coronavirus 229E remains infectious on common touch surface materials. mBio 2015, 6. [CrossRef]

(C) 2020 by the authors. Licensee MDPI, Basel, Switzerland. This article is an open access article distributed under the terms and conditions of the Creative Commons Attribution (CC BY) license (http://creativecommons.org/licenses/by/4.0/). 